\title{
Characterization of Algerian honeys by palynological and physico-chemical methods*
}

\author{
Chahra MAKHLOUFI $^{1}$, Jacob D. KERKVLIET ${ }^{2}$, Giancarlo RICCIARDELli D’ALBORE ${ }^{3}$, \\ Ali CHOUKRI ${ }^{4}, \operatorname{Riad}_{\text {SAMAR }}{ }^{5}$ \\ ${ }^{1}$ Université ibn Khaldoun Tiaret, Faculté des Sciences Agronomiques et Vétérinaires, 14000 Tiaret, Algeria \\ ${ }^{2}$ Netherlands Expertise Centre for Tropical Apicultural Resources, c/o Twickelstraat 9, 7651JH Tubbergen, \\ The Netherlands \\ ${ }^{3}$ Dipartimento di Scienze Agraria Università degli Studi di Perugia, Borgo XX Giugno, 06121 Perugia, Italy \\ ${ }^{4}$ Centre Universitaire de Djelfa. Institut d'Agro pastoralisme, 17000 Djelfa, Algeria \\ ${ }^{5} 10$ route de Sougueur, 14000 Tiaret, Algeria
}

Received 4 July 2009 - Revised 21 October 2009 - Accepted 22 October 2009

\begin{abstract}
Sixty-six Algerian honeys were sampled for investigation on their palynological and physicochemical properties. Results showed that the total number of pollen grains in $10 \mathrm{~g}$ honey ranged from $2.1 \times 10^{3}$ to $1.12 \times 10^{6}$. In total 124 pollen species were identified and the main pollen forms were Eucalyptus spp., Olea europaea, Papaver rhoeas, Pimpinella anisum, Carduus sp. and Hedysarum coronarium. Unifloral eucalypt honeys could be distinguished from other honeys from the western Mediterranean region by the presence of $P$. rhoeas and Centaurea species. Physico-chemical analyses included moisture content, $\mathrm{pH}$, electrical conductivity, diastase, invertase, HMF and 11 sugars. Of these parameters the electrical conductivity was somewhat elevated compared to European honeys, sucrose content was below $4.3 \%$ and only small amounts of di- and trisaccharides were present. In general the samples were found to meet the requirements of the international honey standards.
\end{abstract}

\section{Algeria / electrical conductivity / honey / melissopalynology / sugar}

\section{INTRODUCTION}

Algeria is the second largest country on the African continent. It has an area of about 2.4 million $\mathrm{km}^{2}$ with circa 33.3 million inhabitants. As the country is intersected in the north by the Tell Atlas mountains, which parallel the Mediterranean coast, and by the Saharan Atlas in the south three different environmental and geologic conditions exist. The Tell atlas region enjoys a Mediterranean climate in the coastal areas and is ideal for beekeeping. The main honey flow is during April, May and the first part of June and many trees, cultivated crops and wild plants, like eucalypt (Eucalyptus camaldulensis and E. globulus), orange

Corresponding author: J.D. Kerkvliet, jdkerkvliet@ solcon.nl

* Manuscript editor: Stan Schneider trees (Citrus spp.), sunflower (Helianthus annuus), clover (Trifolium species), French honeysuckle (Hedysarum coronarium), Rosemary (Rosmarinus officinalis) and Thyme (Thymus sp.), provide nectar and pollen for the bees. Also natural forests, including pine trees, are good sources for the bees and it is possible to obtain honey all year round (Hussein, 2000; Ricciardelli D’Albore, 1998).

The centre part of the country consists of high plateaus with plains and some agriculture and in the south we encounter a desert climate. Here in the Saharan desert - constituting $80 \%$ of the country area - the date palm is cultivated but the conditions for beekeeping are unfavourable (Nedjraoui, 1981, 2001; Hadjiat, 1997). In the north part of the country beekeeping plays an important role. There is migratory beekeeping for honey production, but 
bees are usually not transported for pollination. It is estimated that the yearly honey production reaches 800 tonnes (Hussein, 2000). Good quality honey is highly appreciated by the consumer but due to limited knowledge by beekeepers a high standard product is not always achieved.

In general the main physico-chemical quality criteria for honey are moisture, HMF and enzyme content. In the international standards values for these and other parameters are specified (Codex Alimentarius Commission, 2001; European Commission, 2002; IHC website). The moisture content determines the capability of the product to remain stable and to resist spoilage by yeast fermentation. Maximum value is set at $20 \%$ by weight. As quality test for freshness and marker for overheating the activity of the enzyme diastase ( $\alpha$-amylase) is measured (minimum 8 units) and additionally in some countries the invertase activity. The amount of HMF, which stands for 5-hydroxy methyl furfural, a degradation product of fructose, is about $3 \mathrm{mg} / \mathrm{kg}$ for fresh and unheated honey but increases during storage, heating and processing. HMF-content is a world wide used important quality criterion and the maximum quantity allowed is $40 \mathrm{mg} / \mathrm{kg}$.

To verify the botanical origin the determination of the electrical conductivity and melissopalynology (pollen analysis) are used in control laboratory. Besides the sugar spectrum can give information on this topic.

There are a few publications concerning the pollen spectrum of multifloral and unifloral honeys produced in Algeria. In the past Louveaux and Abed (1984) performed an extensive melissopalynological research on honey samples from north Africa, including 59 samples from mainly northern Algeria and Ricciardelli D'Albore (1998) mentions the main pollen types in the Mediterranean area of Algeria. An undated study published on internet (Chefrour and Tahar) reported the pollen found in six honey samples collected in east Algeria. Recently two studies, describing the melissopalynological properties together with some physico-chemical quality parameters were published. One of these concerned a research in which 11 honeys were involved (Ouchemoukh et al., 2007); in the other
(Chefrour et al., 2007) the quality of 13 honeys from northeast Algeria was evaluated. However only a limited number of honey samples were analyzed in these studies.

In order to contribute to the knowledge of the properties of multifloral and unifloral honeys from Algeria in more detail we carried out a survey on 66 honey samples originating from the main beekeeping areas, subdivided in four regions east, centre, west and south. It was our aim to characterize the honeys from these four regions by their palynological and physico-chemical properties, to compare the data with those from other honeys from the western Mediterranean area and to check if the requirements of the international standards (Codex Alimentarius Commission, 2001; European Commission, 2002; IHC website) are met. Palynological analysis was done in combination with moisture content, $\mathrm{pH}$, electrical conductivity, diastase number, invertase number, hydroxymethylfurfural (HMF) and the sugar spectrum as additional criteria.

The official harmonised methods of analyses of the International Honey Commission, as published in an extra issue of Apidologie (Bogdanov et al., 1997), were followed in this study. Recently these (updated) methods were made available through the website of the International (former: European) Honey Commission (IHC website).

Also some other quality criteria were determined but their results and compliance with the international standards were published elsewhere (Makhloufi et al., 2007). Up to now no study was known to the authors that focussed on the melissopalynological properties as well as on the sugar spectrum and enzyme activity of honeys harvested in Algeria.

\section{MATERIAL AND METHODS}

\subsection{Honey samples}

During the years 2003-2005, 66 honey samples (500 $\mathrm{g}$ each), produced mainly in the Tell Atlas region of Algeria, were collected on 22 locations. They originated directly from beekeepers (59 samples) or from apicultural corporations (seven samples). Twenty samples came from the west part of 


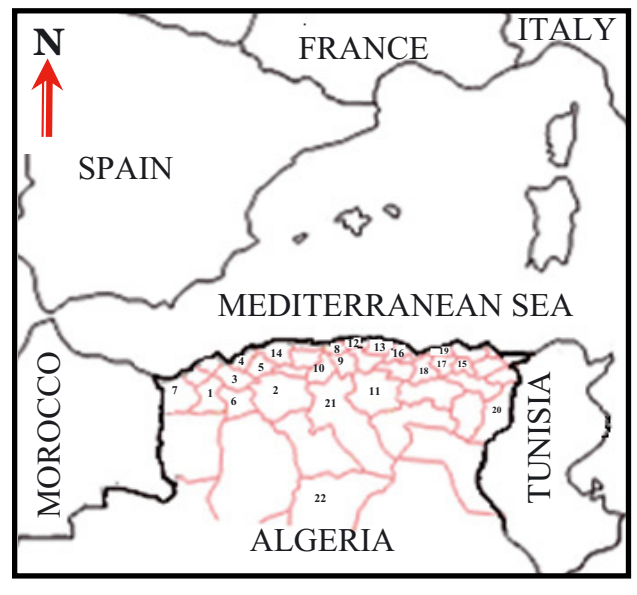

$\begin{array}{ll}\text { 1. Sidi Bel Abbes } & \text { 12. Boumerdes } \\ \text { 2. Tiaret } & \text { 13. Tizi Ouzou } \\ \text { 3. Mascara } & \text { 14. Chlef } \\ \text { 4. Mostagane } & \text { 15. Constantine } \\ \text { 5. Relizane } & \text { 16. Jijel } \\ \text { 6. Saida } & \text { 17. Mila } \\ \text { 7. Tlemcen } & \text { 18. Sétif } \\ \text { 8. Alger } & \text { 19. Skikda } \\ \text { 9. Blida } & \text { 20. Tébessa } \\ \text { 10. Khemis Miliana } & \text { 21. Djelfa } \\ \text { 11. Médéa } & \text { 22. Ghardaia }\end{array}$

Figure 1. Map of the geographical origin of the honey samples.

the region, 34 samples were from the centre part, eight samples from the east and four from the south. All samples were kept refrigerated until analysis. Details of the sampling locations are shown in Figure 1 and Table I.

\subsection{Methods of analysis}

\subsubsection{Melissopalynological analyses}

Quantitative melissopalynological analysis was performed according to Maurizio's method (Louveaux et al., 1978) by counting microscopically the number of pollen present in the honey sediment after centrifuging a honey solution. Pollen in 100 fields of view were counted in four fold. The results were based on the average number in the 400 fields of view and expressed as the number of pollen grains in $10 \mathrm{~g}$ honey $(\mathrm{PG} / 10 \mathrm{~g})$ in thousands $\left(10^{3}\right)$ and rounded to the nearest thousand. The honeys were placed into one of the five pollen representativity classes as distinguished by Maurizio (Louveaux et al., 1978; Von der Ohe et al., 2004). Class I includes honeys poor in pollen $\left(\mathrm{PG} / 10 \mathrm{~g}<20 \times 10^{3}\right)$, class II includes honeys with normal pollen representativity $\left(20 \times 10^{3}-100 \times 10^{3}\right)$, class III honeys with over-represented pollen $\left(100 \times 10^{3}-500 \times 10^{3}\right)$, class IV with strongly over-represented pollen $\left(500 \times 10^{3}-10^{6}\right)$ and class $\mathrm{V}$ includes pressed honeys ( $\mathrm{PG} / 10 \mathrm{~g}>10^{6}$ pollen).

Qualitative melissopalynological analysis - the types of pollen grains with their percentages in the pollen sediment - was carried out by dissolving the honey in dilute sulphuric acid, centrifuging the solution and mounting the sediment in Kaiser's Glycerol Gelatine ${ }^{\mathrm{TM}}$ (glycerine jelly). For each sample 300 pollen were counted and their relative frequency classes were determined, using the terms 'very frequent' (for pollen constituting $>45 \%$ of the total), 'frequent' (16-45\%), 'rare' (3-15\%) and 'sporadic' $(<3 \%)$. According to the international melissopalynological nomenclature pollen occurring 'very frequent', resp. 'frequent' are called predominant, resp. secondary pollen; pollen occurring rare and sporadic are called important minor pollen and minor pollen (Louveaux et al., 1978). For all pollen species in the 66 samples the individual occurrence was calculated and expressed as percentage of the total studied samples in which the determined pollen type was found. Identification of pollen was done by use of microphotographs and by preparing a reference collection of pollen of a great number of plants of known scientific and local names.

\subsubsection{Physico-chemical analyses}

All physico-chemical determinations mentioned above, except $\mathrm{pH}$ measurements, were carried out according to the harmonised methods of the International Honey Commission (Bogdanov et al., 1997; IHC website). The principle and the instrumental details of the methods were as follows.

For measuring the water content (moisture) an Abbe refractometer was used.

Electrical conductivity was determined by using a Consort C951 conductometer.

For the determination of the enzyme diastase ( $\alpha$ and $\beta$-amylase) the Phadebas procedure was followed. The absorbance was measured with a Varian spectrophotometer, type UV visible Cary 50.

The measurement of the enzyme invertase $(\alpha$ glucosidase) was done following the method of Siegenthaler as harmonised by the International Honey Commission (Bogdanov et al., 1997). The absorbance was measured at $400 \mathrm{~nm}$ with a Varian spectrophotometer type UV visible Cary 50. 
Table I. Places of origin, the number of pollen grains in 10 gram, pollen representativity according to Maurizio's classes and predominant and secondary pollen types in 66 honey samples.

\begin{tabular}{|c|c|c|c|c|}
\hline $\begin{array}{l}\text { Sample } \\
\text { number }\end{array}$ & Place of origin & $\begin{array}{l}\text { Number of } \\
\text { pollen in } 10 \mathrm{~g} \\
(\mathrm{PG} / 10 \mathrm{~g}) \\
\times 10^{3}\end{array}$ & $\begin{array}{l}\text { Pollen } \\
\text { class }\end{array}$ & Predominant and secondary pollen types \\
\hline \multicolumn{5}{|l|}{ West } \\
\hline E7 & Relizane & 13.9 & I & Olea europaea + Citrus \\
\hline E18 & Tiaret & 1019.6 & $\mathrm{~V}$ & Pimpinella anisum \\
\hline E38 & Tiaret & 25.2 & II & Vicia \\
\hline E43 & Tiaret & 7.3 & I & Multifloral + Aster \\
\hline E44 & Tiaret & 24.1 & II & Multifloral + Pimpinella anisum + Daucus carota \\
\hline E45 & Mostaganem & 23.0 & II & Eucalyptus \\
\hline E46 & Relizane & 9.9 & I & Citrus \\
\hline E47 & Mascara & 34.8 & II & Multifloral + Olea europaea + Hedysarum coronarium \\
\hline E48 & Tiaret & 160.1 & III & $\begin{array}{l}\text { Multifloral }+ \text { Pimpinella anisum }+ \text { Hedysarum coronarium }+ \\
\text { Trifolium alexandrinum }\end{array}$ \\
\hline E49 & Tiaret & 148.2 & III & Eucalyptus \\
\hline E50 & Tiaret & 18.0 & I & Multifloral + Eucalyptus \\
\hline E54 & Tiaret & 180.0 & III & Pimpinella anisum \\
\hline E55 & Tiaret & 18.2 & I & Eucalyptus \\
\hline E56 & Saida & 440.0 & III & Centaurea + Olea europaea \\
\hline E57 & Sidi Bel Abbes & 390.0 & III & Sedum-type \\
\hline E60 & Tiaret & 15.5 & I & Eucalyptus \\
\hline E62 & Tlemcen & 2.7 & I & Pimpinella anisum \\
\hline E63 & Tiaret & 34.0 & II & Eucalyptus \\
\hline E64 & Tiaret & 23.5 & II & Hedysarum coronarium \\
\hline E66 & Tiaret & 5.7 & I & Eucalyptus \\
\hline \multicolumn{5}{|l|}{ Centre } \\
\hline E1 & Tizi Ouzou & 46.4 & II & Hedysarum coronarium \\
\hline E2 & Tizi Ouzou & 114.3 & III & Hedysarum coronarium \\
\hline E3 & Tizi Ouzou & 1120.4 & $\mathrm{~V}$ & Hedysarum coronarium \\
\hline E4 & Alger & 10.4 & I & Olea europaea + Echium plantagineum \\
\hline E5 & Alger & 21.6 & II & Multifloral + Eucalyptus + Echium plantagineum \\
\hline E6 & Alger & 20.1 & II & Eucalyptus \\
\hline E8 & Alger & 53.9 & II & Eucalyptus \\
\hline E13 & Alger & 24.3 & II & Eucalyptus \\
\hline E14 & Alger & 47.9 & II & Eucalyptus \\
\hline E15 & Blida & 4.5 & I & Multifloral + Olea europaea + Trifolium repens \\
\hline E16 & Blida & 27.1 & II & Multifloral + Reseda \\
\hline E17 & Tizi Ouzou & 140.4 & III & Multifloral + Cistus + Centaurea cyanus \\
\hline E19 & Alger & 42.3 & II & Eucalyptus \\
\hline E20 & Blida & 7.5 & I & Multifloral + Trifolium repens \\
\hline E21 & Blida & 183.8 & III & Multifloral + Eucalyptus + Pimpinella anisum \\
\hline E22 & Tizi Ouzou & 45.7 & II & Pimpinella anisum \\
\hline E23 & Tizi Ouzou & 404.3 & III & Multifloral + Eucalyptus + Echium plantagineum \\
\hline E24 & Tizi Ouzou & 149.6 & III & Multifloral + Echium plantagineum + Trifolium pratense \\
\hline E25 & Boumerdes & 75.4 & II & Multifloral + Eucalyptus + Hedysarum coronarium \\
\hline E27 & Médéa & 14.1 & II & Multifloral + Pimpinella anisum + Hedysarum coronarium \\
\hline E31 & Médéa & 29.8 & II & Daucus carota \\
\hline E33 & Chlef & 114.9 & III & Multifloral + Eucalyptus + Pimpinella anisum \\
\hline E34 & Blida & 49.2 & II & Multifloral + Rubus + Daucus carota + Eryngium \\
\hline E35 & Alger & 92.6 & II & Eucalyptus \\
\hline E36 & Alger & 19.7 & I & Eucalyptus \\
\hline E37 & Tizi-Ouzou & 10.0 & I & Hedysarum coronarium \\
\hline E39 & Blida & 8.5 & I & Multifloral + Pimpinella anisum + Daucus carota \\
\hline $\mathrm{E} 40$ & Blida & 7.1 & I & Multifloral \\
\hline E41 & \multicolumn{2}{|c|}{ Khemis Melyana111.6 } & III & Eucalyptus \\
\hline E42 & Blida & 52.1 & II & Pimpinella anisum \\
\hline E51 & Chlef & 31.2 & II & Citrus + Olea + Centaurea \\
\hline E59 & Médéa & 4.9 & I & Multifloral + Pimpinella anisum + Scilla bifolia \\
\hline E61 & Blida & 53.2 & II & Eucalyptus \\
\hline E65 & Médéa & 15.6 & $\mathrm{I}$ & Pimpinella anisum \\
\hline
\end{tabular}


Table I. Continued.

\begin{tabular}{|c|c|c|c|c|}
\hline $\begin{array}{l}\text { Sample } \\
\text { number }\end{array}$ & Place of origin & $\begin{array}{l}\text { Number of } \\
\text { pollen in } 10 \mathrm{~g} \\
(\mathrm{PG} / 10 \mathrm{~g}) \times 10^{3}\end{array}$ & $\begin{array}{l}\text { Pollen } \\
\text { class }\end{array}$ & Predominant and secondary pollen types \\
\hline \multicolumn{5}{|l|}{$\overline{\text { East }}$} \\
\hline E9 & Sétif & 211.6 & III & Hypecoum + Helianthus annuus \\
\hline E10 & Skikda & 9.9 & I & Multifloral + Trifolium repens + Onosis \\
\hline E11 & Jijel & 63.6 & II & Hedysarum coronarium \\
\hline E26 & Tébessa & 159.2 & III & Rubus + Rosmarinus officinalis \\
\hline E30 & Sétif & 18.4 & I & Multifloral + Echium plantagineum \\
\hline E32 & Constantine & 85.7 & II & Multifloral + Echium plantagineum + Trifolium pratense \\
\hline E52 & Constantine & 2.1 & I & Multifloral + Hedysarum coronarium + Trifolium alexandrinum \\
\hline E53 & Mila & 2.6 & I & Hedysarum coronarium \\
\hline \multicolumn{5}{|l|}{ South } \\
\hline E12 & Ghardaia & 145.5 & III & Eucalyptus \\
\hline E28 & Djelfa & 36.5 & II & Tamarix \\
\hline E29 & Djelfa & 51.6 & II & Rubus \\
\hline E58 & Djelfa & 35.1 & II & Eucalyptus \\
\hline
\end{tabular}

HMF was done by the Winkler method. The resulting colour was measured at $550 \mathrm{~nm}$ with a Varian spectrophotometer, type UV visible Cary 50.

The monosaccharide sugars glucose and fructose, the disaccharides sucrose, maltose, isomaltose, melibiose, turanose and trehalose and the trisaccharides melicitose, raffinose and erlose were determined by HPLC over a strong anion exchange resin with pulsed amperometric detection. Some years ago the method was subjected to a ring trial with seven laboratories by the European Honey Commission for fructose, glucose and sucrose (Bogdanov et al., 1997; IHC website).

For $\mathrm{pH}$ determination 5 gram honey was diluted to $50 \mathrm{~mL}$ and the $\mathrm{pH}$ value was measured with an Orion 940/960 pH meter (Journal Officiel Français, 1977).

\subsubsection{Statistical analyses}

In order to estimate if there was a statistically significant difference in the physico-chemical composition of the honey samples from the four regions one-way ANOVA analysis was applied to the data. For all honeys correlation analysis was performed between the parameters.

\section{RESULTS}

\subsection{Quantitative melissopalynological analysis}

As illustrated in Table I the PG/10 g for all samples ranged from $2.1 \times 10^{3}$ to $1.12 \times 10^{6}$. In this table the samples are arranged according to their geographical region.

Twenty-two of the 66 samples $(33.3 \%)$ were poor in pollen $\left(<20 \times 10^{3}\right.$ in $\left.10 \mathrm{~g}\right)$ and belonged consequently to class I; 27 samples $(40.9 \%)$ belonged to class II with normal representativity $\left(20 \times 10^{3}-100 \times 10^{3}\right.$ in $10 \mathrm{~g}) ; 15$ samples $(22.7 \%)$ felt into class III $\left(100 \times 10^{3}-500 \times 10^{3}\right.$ in $\left.10 \mathrm{~g}\right)$ and 2 samples $(3.0 \%)$ in class $\mathrm{V}$; they contained more than $10^{6}$ pollen in $10 \mathrm{~g}$, an indication for pressed honeys.

\subsection{Qualitative melissopalynological analysis}

In qualitative pollen analysis a total of 124 pollen species were identified. The number of pollen forms per sample ranged from nine (in samples E3 and E4) to 31 (E64), with an average value of 14 . For all 66 samples the presence of the 23 predominant and secondary pollen species is shown in Table I and for the main 30 pollen types, present in more than $15 \%$ of the honey samples, the individual pollen occurrence expressed as percentage of the total studied samples - with a subdivision in the four relative frequency classes 'very frequent', 'frequent', 'rare' and 'sporadic' - is given in Figure 2.

\subsection{Unifloral honeys}

From melissopalynological and physicochemical data and from sensorial analysis 


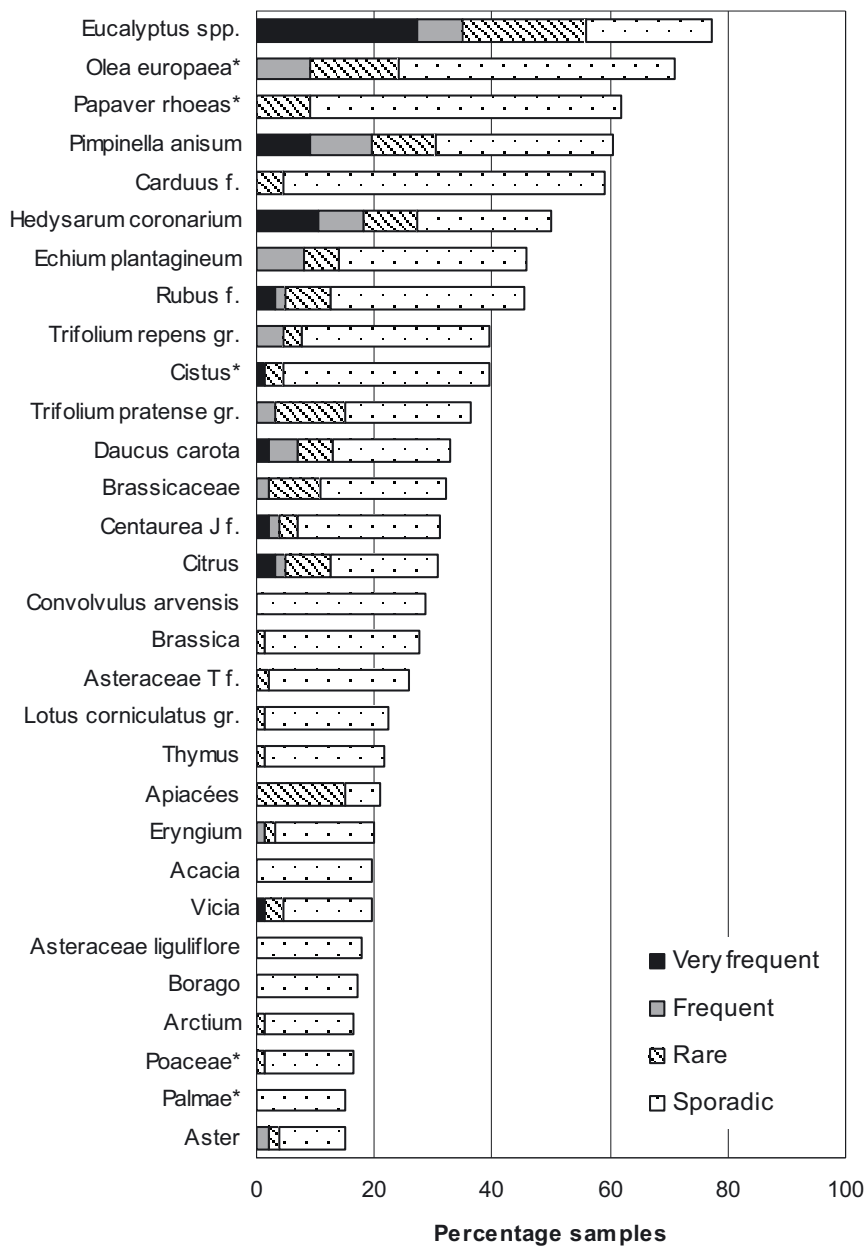

Figure 2. Pollen occurrence of the main thirty pollen types expressed as percentage of the total studied samples - with a subdivision in the four relative frequency classes 'very frequent', 'frequent', 'rare' and 'sporadic'. ${ }^{*}=$ nectarless species.

18 honeys could be classified for sure as unifloral: honey obtained from Eucalyptus spp. (14 samples), Citrus spp. (two), Helianthus annuus (one) and Rosmarinus officinalis (one).

\subsection{Physico-chemical and statistical analyses}

The mean value, the range and the standard deviation (s.d.) of the physico-chemical parameters are given in Tables II and III.

With ANOVA analysis only for the region south a striking difference was found in $\mathrm{pH}$ compared with the other regions $(F=12.410$, $P=0.000)$. Correlation analysis showed a linear positive relationship between the diastase and invertase activity and a negative between diastase and HMF and between invertase and HMF as is illustrated in Table IV.

\section{DISCUSSION}

\subsection{Quantitative melissopalynological analysis}

The observed pollen distribution is quite normal for Mediterranean honey (Persano 
Table II. Physico-chemical data for multifloral and some unifloral honeys from Algeria.

\begin{tabular}{lccc}
\hline Parameter & $\begin{array}{c}\text { Multifloral } \\
n=48\end{array}$ & $\begin{array}{c}\text { Eucalyptus } \\
n=14\end{array}$ & $\begin{array}{c}\text { Citrus } \\
n=2\end{array}$ \\
\hline Water $(\% \mathrm{~m} / \mathrm{m})$ & $16.5 \pm 1.6$ & $16.5 \pm 1.7$ & $16.8 \pm 0.3$ \\
$\quad$ Mean \pm s.d. & $14.0-20.2$ & $14.0-19.8$ & $16.6-17.0$ \\
$\quad$ Range & $3.93 \pm 0.45$ & $4.00 \pm 0.20$ & $4.00 \pm 0.10$ \\
$\mathrm{pH}$ & $3.40-6.23$ & $3.70-4.30$ & $3.90-4.10$ \\
$\quad$ Mean \pm s.d. & & & \\
$\quad$ Range & $0.55 \pm 0.18$ & $0.60 \pm 0.20$ & $0.40 \pm 0.20$ \\
El. conductivity $(\mathrm{mS} / \mathrm{cm})$ & $0.11-0.93$ & $0.10-0.90$ & $0.30-0.50$ \\
$\quad$ Mean \pm s.d. & $18.0 \pm 9.29$ & $15.9 \pm 6.89$ & $8.0 \pm 1.41$ \\
$\quad$ Range & $4.0-40.0$ & $8.0-30.0$ & $7.0-9.0$ \\
Diastase number & & & \\
$\quad$ Mean \pm s.d & $7.90 \pm 4.76$ & $9.64 \pm 6.06$ & $2.5 \pm 0.71$ \\
$\quad$ Range & $0-17.00$ & $1.0-20.0$ & $2.0-3.0$ \\
Invertase number & & & \\
$\quad$ Mean \pm s.d & $17.18 \pm 18.42$ & $25.63 \pm 27.24$ & $3.11 \pm 1.31$ \\
$\quad$ Range & $0.50-123.98$ & $5.84-110.70$ & $2.18-4.03$ \\
HMF $\left(\mathrm{mg} \mathrm{kg}{ }^{-1}\right)$ & & & \\
$\quad$ Mean $\pm \mathrm{s.d}$ & $112.1 \pm 226.2$ & $56.9 \pm 47.6$ & $11.9 \pm 2.8$ \\
$\quad$ Range & $2.1-1120.4$ & $15.5-148.2$ & $9.9-13.9$ \\
PG/10g $(\times 1000)$ & &
\end{tabular}

Oddo and Piro, 2004) and also corresponded with the results of an earlier unpublished study of one of the authors (CM) on the pollen richness of 50 Algerian honeys in which the values for the PG/10 $\mathrm{g}$ for the classes I, II and III were respectively $28 \%, 56 \%$, and $16 \%$. Ouchemoukh et al. (2007) found in their study of 11 Algerian samples lower PG/10 g values, ranging from $20 \times 10^{3}$ till $40 \times 10^{3}$. Their samples were collected in various regions of the province Bejaia, situated along the Mediterranean coast. However many factors influence the number of pollen in honey. It is known that the pollen richness depends upon the pollen production of the plant, the weather conditions, the distance of the beehive to the flower field, the filtering by the bee's proventriculus and consequently the pollen's diameter, and the mode of honey extraction (Von der Ohe, 1994). If honey is harvested by pressing the combs the amount of pollen usually exceeds $10^{6}$ pollen in $10 \mathrm{~g}$, due to the presence of stored pollen for bee nutrition. In that case pollen analysis is of no use in determining the botanical origin of the product.

\subsection{Qualitative melissopalynological analysis}

In the majority of the samples pollen from Eucalyptus species (77\%), Olea europaea (olive tree) (71\%), Papaver rhoeas (corn or field poppy) (62\%), Pimpinella anisum (aniseed), (61\%), a cultivated herb and Carduus sp. (thistle) (59\%) were present, while Hedysarum coronarium was identified in 50\% of the collected samples. Eucalyptus spp. as well as $H$. coronarium are very characteristic plant species and good nectar sources, found throughout Algeria. Honeys from H. coronarium are also found in Italy (Ricciardelli d'Albore, 1998). The characteristic O. europea and $P$. rhoeas are no nectar suppliers but are good pollen sources for the bees.

Pimpinella anisum pollen were frequently encountered in the honey samples from the centre region. As this plant is a good nectariferous species, it plays an important role in apiculture throughout north Africa and already Louveaux and Abed (1984) noted that pollen of the Apiaceae family were abundant 
Table III. Sugar spectrum for multifloral and some unifloral honeys from Algeria.

\begin{tabular}{|c|c|c|c|}
\hline Parameter & $\begin{array}{c}\text { Multifloral } \\
n=48\end{array}$ & $\begin{array}{c}\text { Eucalyptus } \\
n=14\end{array}$ & $\begin{array}{l}\text { Citrus } \\
n=2\end{array}$ \\
\hline \multicolumn{4}{|l|}{ Glucose $(\% \mathrm{~m} / \mathrm{m})$} \\
\hline Mean \pm s.d. & $28.96 \pm 2.91$ & $29.70 \pm 2.94$ & $27.00 \pm 2.05$ \\
\hline Range & $21.20-35.20$ & $24.20-34.00$ & $25.50-28.40$ \\
\hline \multicolumn{4}{|c|}{ Fructose $(\% \mathrm{~m} / \mathrm{m})$} \\
\hline Mean \pm s.d. & $41.82 \pm 3.55$ & $42.10 \pm 3.31$ & $41.20 \pm 2.33$ \\
\hline Range & $34.00-49.10$ & $34.20-47.60$ & $39.50-42.80$ \\
\hline \multicolumn{4}{|l|}{ Sucrose $(\% \mathrm{~m} / \mathrm{m})$} \\
\hline Mean \pm s.d. & $1.15 \pm 1.06$ & $1.10 \pm 0.50$ & $0.50 \pm 0.70$ \\
\hline Range & $0-4.30$ & $0.40-2.10$ & $0-1.00$ \\
\hline \multicolumn{4}{|c|}{ Maltose $(\% \mathrm{~m} / \mathrm{m})$} \\
\hline Mean \pm s.d. & $1.60 \pm 0.89$ & $1.70 \pm 0.60$ & $1.40 \pm 0.50$ \\
\hline Range & $0-5.40$ & $0.70-2.60$ & $1.00-1.70$ \\
\hline \multicolumn{4}{|c|}{ Isomaltose $(\% \mathrm{~m} / \mathrm{m})$} \\
\hline Mean \pm s.d. & $1.12 \pm 0.87$ & $0.70 \pm 0.40$ & $1.10 \pm 0.20$ \\
\hline Range & $0-4.80$ & $0.20-1.80$ & $0.90-1.20$ \\
\hline \multicolumn{4}{|c|}{ Melibiose $(\% \mathrm{~m} / \mathrm{m})$} \\
\hline Mean \pm s.d. & $0.01 \pm 0.06$ & 0 & 0 \\
\hline Range & $0-0.40$ & 0 & 0 \\
\hline \multicolumn{4}{|c|}{ Turanose $(\% \mathrm{~m} / \mathrm{m})$} \\
\hline Mean \pm s.d. & $1.28 \pm 0.88$ & $1.00 \pm 0.60$ & $0.80 \pm 0.20$ \\
\hline Range & $0-3.70$ & $0-2.10$ & $0.60-0.90$ \\
\hline \multicolumn{4}{|c|}{ Trehalose $(\% \mathrm{~m} / \mathrm{m})$} \\
\hline Mean \pm s.d. & $0.01 \pm 0.04$ & $0 \pm 0.10$ & 0 \\
\hline Range & $0-0.20$ & $0-0.20$ & 0 \\
\hline \multicolumn{4}{|l|}{ Melicitose } \\
\hline Mean \pm s.d. & $0.04 \pm 0.12$ & $0.10 \pm 0.10$ & 0 \\
\hline Range & $0-0.50$ & $0-0.40$ & 0 \\
\hline \multicolumn{4}{|l|}{ Raffinose } \\
\hline Mean \pm s.d. & $0.08 \pm 0.17$ & $0.20 \pm 0.50$ & 0 \\
\hline Range & 0-0.90 & $0-1.70$ & 0 \\
\hline \multicolumn{4}{|l|}{ Erlose } \\
\hline Mean \pm s.d. & $0.49 \pm 0.74$ & $0.20 \pm 0.30$ & $0.30 \pm 0.40$ \\
\hline Range & $0-3.70$ & $0-0.60$ & $0-0.50$ \\
\hline \multicolumn{4}{|c|}{ Fructose+glucose } \\
\hline Mean \pm s.d. & $70.8 \pm 5.05$ & $71.8 \pm 4.76$ & $68.1 \pm 0.28$ \\
\hline Range & $55.2-79.8$ & $60.8-78.8$ & $67.9-68.3$ \\
\hline
\end{tabular}

in honeys from this region. They only identified this pollen type to family level and not to a specific genus or species. Eastward from Algeria, in Tunisia, the occurrence of Apiaceae pollen of the Pimpinella group in local honey was already reported by Vorwohl (1973), together with pollen from Acacia spp, Papaver, Olea, Myrtaceae and Cistus spp. Also in Turkey monofloral Pimpinella honeys are known (Ricciardelli d'Albore, 1998). However, more westward, no mention is made of this member of the Apiaceae family in Moroccan honey (Damblon, 1987, 1988; Terrab et al., 2003a-d).

As illustrated in Figure 2 other pollen species characteristic for the Algerian honey samples were: Echium plantagineum (Viper's Bugloss), Trifolium spp., Rubus sp. and Cistus sp. (rockrose). In fact they were represented in approximately $40 \%$ of the honeys and sometimes reached the level of predominant pollen. Of the cultivated crops, the genera Brassica 
Table IV. Correlation coefficients of some physicochemical parameters.

\begin{tabular}{lccc}
\hline Parameter 1 & Parameter 2 & $\begin{array}{c}\text { Correlation } \\
\text { coefficient }\end{array}$ & Probability \\
\hline Diastase & HMF & -0.32 & $P<0.05$ \\
Invertase & HMF & -0.47 & $P<0.05$ \\
Diastase & Invertase & 0.47 & $P<0.05$ \\
\hline
\end{tabular}

and Citrus, the latter especially cultivated in coastal areas, were found in about $30 \%$ of the samples and the species Helianthus annuus occurred in more than $10 \%$ of the honeys. As far as the main pollen species are concerned our results are in agreement with Louveaux and Abed (1984), Chefrour et al. (2007) and Ouchemoukh et al. (2007).

The most important plants for the honey flow were derived from Table I by counting in each of the four regions the number of honey samples with primary and secondary pollen of nectariferous plants. The results are expressed as percentage of the studied samples in the specific region and shown in Table V. Especially the centre region is rich in plants which supply appreciable amounts of honey. In three regions (west, centre and south), Hedysarum coronarium, clover and Eucalyptus spp. contribute to a considerable extent to the honey yield, Daucus carota and Pimpinella anisum are more confined to the regions west en centre and Echium plantagineum to centre and east.

\subsection{Unifloral honeys}

\subsubsection{Eucalyptus honey}

It is known that eucalypt pollen is overrepresented in honey. However fourteen of our samples could be considered as unifloral Algerian eucalypt honeys because they contained more than $70 \%$ Eucalyptus pollen and because their physico-chemical and sensorial properties were in accordance with the standards as described by Persano Oddo and Piro (2004). The most important accompanying pollen were Echium plantagineum, Olea europaea, Trifolium spp., Papaver rhoeas, Centaurea sp. and Apiaceae. PG/10 g ranged from $5.7 \times 10^{3}-148 \times 10^{3}$ with a mean value of $56.9 \times 10^{3}$.
Table V. Main honey producing plants in four regions of Algeria. Number of honey samples in each region with primary and secondary pollen of nectariferous plants expressed as percentage of the studied samples in the specific region.

\begin{tabular}{|c|c|c|c|c|}
\hline $\begin{array}{l}\text { Nectariferous plant } \\
\text { species }\end{array}$ & $\begin{array}{c}\text { West } \\
\%\end{array}$ & $\begin{array}{c}\text { Centre } \\
\%\end{array}$ & $\begin{array}{c}\text { East } \\
\%\end{array}$ & $\begin{array}{c}\text { South } \\
\%\end{array}$ \\
\hline Eucalyptus spp. & 35 & 41 & & 50 \\
\hline Pimpinella anisum & 25 & 23 & & \\
\hline $\begin{array}{l}\text { Hedysarum coronar- } \\
\text { ium }\end{array}$ & 15 & 18 & 38 & \\
\hline Citrus spp. & 10 & 3 & & \\
\hline Daucus carota & 5 & 9 & & \\
\hline Echium plantagineum & & 12 & 25 & \\
\hline Clover spp. & 5 & 9 & 37 & \\
\hline Rubus sp. & & 3 & & 25 \\
\hline Vicia sp. & 5 & & & \\
\hline Aster sp. & 5 & & & \\
\hline Centaurea sp. & & 3 & & \\
\hline Scilla bifolia & & 3 & & \\
\hline Helianthus anпииs & & & 12 & \\
\hline Onosis sp. & & & 12 & \\
\hline Rosmarinus & & & & \\
\hline officinalis & & & 12 & \\
\hline Tamarix sp. & & 25 & & \\
\hline Eryngium sp. & & 3 & & \\
\hline
\end{tabular}

Also Louveaux and Abed (1984) observed that Eucalypt was one of the most important bee plants in Algeria. It was likewise noticed that its pollen plays a predominant role in honey from Tunisia (unpublished study by CM) and Terrab et al. (2003a) concluded that unifloral honeys from Eucalyptus camaldulensis Dehnh are very common in north Morocco. They mentioned Plantago sp. and Thymelaceae pollen as accompanying flora, while Ricciardelli d'Albore and Vorwohl (1980) found species of Acacia, Gleditsia and Hedysarum coronarium as accompanying pollen for Libya. According to the same authors Tunisian eucalypt honeys were characterized by species of Citrus and Acacia together with Erica multiflora, Olea europaea, and Hedysarum coronarium as accompanying pollen. Spanish eucalypt honeys distinguish themselves from other eucalypt honeys from the western Mediterranean region by having Cytisus, Lotus, Salix, Rubus, Asteraceae and Scrophulariaceae spp. in their pollen spectrum (Seijo et al., 2003). 


\subsubsection{Other unifloral honey types}

Citrus pollen is usually underrepresented in honey. Nevertheless, three samples contained quite a high percentage of Citrus pollen (20$55 \%$ ) and two of them complied with the unifloral type (Persano Oddo and Piro, 2004). Characteristic for the pollen spectrum was the presence of Convolvulus pollen. Total number of pollen in 10 gram ranged from $9.9 \times$ $10^{3}-13.9 \times 10^{3}$. Unifloral Citrus honeys were also harvested in northwest Morocco (Terrab et al., 2003b), Spain, Cyprus (Ricciardelli d'Albore and Vorwohl, 1980) and Tunisia (Louveaux and Abed, 1984). Two honey samples, one with Rosmarinus officinalis and one with Helianthus annuus pollen proved to be unifloral by their physico-chemical, sensorial and melissopalynological properties but no definite conclusions about the characteristic pollen spectrum of these honey types may be drawn from one sample.

\subsection{Physical analyses and honey quality}

Moisture content for all 66 samples was in the range 13.9 to $20.2 \%$. Except for one sample all honeys were below the maximum value of $20 \%$ mentioned in the international standard (Codex Alimentarius Commission, 2001) and the EC directive (European Commission, 2002). Lowest value encountered was $13.9 \%$ in sample E9 originating from Sétif situated in a region with a warm and dry climate (semi aride). Concerning the honey quality: it is interesting to note that only $12 \%$ of the samples had a water content over $18 \%$ - a threshold value above which there is a risk of fermentation (Schweizer, 1998). Ouchemoukh et al. (2007) found in 11 honey samples from Bejaia (Algeria) values from 14.6 to $19.0 \%$ and in the publication of Chefrour et al. (2007) the water content ranged from 16.0 to $20.4 \%$. For Tunisian honeys values ranged from 16.0 $21.8 \%$ (Jilani et al., 2008) and Terrab et al. (2003a) observed in 29 Moroccan eucalypt honeys a mean water content of $17.5 \%$ (range $14.5-19.9 \%$ ), well within the range of our results for this honey type.

The $\mathrm{pH}$ for all honeys varied between 3.40 and 6.23. There are no fixed limits for $\mathrm{pH}$ val- ues however this parameter may be used as an indication of the botanical origin. Values above 5.0 usually point to honeydew honey and two of our samples, with pH 5.00 and 6.23 (E28 and E58), should on this basis be considered as possibly originating from honeydew. Yet, due to an elevated content of higher sugars, only sample E58 could be identified as partly derived from honeydew. Other authors mentioned $\mathrm{pH}$ values for Algerian multifloral honeys between 3.49 and 4.43 (Ouchemoukh et al., 2007). For Moroccan eucalypt honeys a pH range of 2.25-4.17 was found with an average of 3.64 (Terrab et al., 2003a) which is lower than in our study and lower than the mean $\mathrm{pH}$ of 4.0 for Italian eucalypt honeys (Persano Oddo and Piro, 2004). For Citrus honeys the $\mathrm{pH}$ of our two Algerian samples were in line with the $\mathrm{pH}$ values found by Terrab et al. (2003b) and by Persano Oddo and Piro (2004).

The electrical conductivity depends largely on the botanical origin. For many types of European unifloral honeys a mean value and range was established for this parameter (Persano Oddo and Piro, 2004). According to the EU directive (European Commission, 2002) nectar honey should have a conductivity of no more than $0.8 \mathrm{mS} / \mathrm{cm}$. Higher values are considered as belonging to honeydew honey or mixtures of honeydew and nectar honey. There are however some exceptions to this limit, Eucalyptus honey being one of them. The conductivity of our 48 unifloral honeys was rather elevated with an average value of $0.55 \mathrm{mS} / \mathrm{cm}$ but in only one instance we noticed a value higher than the limit for nectar honey $(0.93 \mathrm{mS} / \mathrm{cm}$ in sample E42). However the $\mathrm{pH}$ and sugar spectrum of this honey gave no indication for honeydew. Also elevated was the mean value for our 14 eucalypt honeys $(0.60 \pm 0.20 \mathrm{mS} / \mathrm{cm})$ compared to European eucalypt honeys $(0.48 \pm 0.6 \mathrm{mS} / \mathrm{cm})$ (Persano Oddo and Piro, 2004). It should be emphasized that the climatologic and soil conditions are different in north Africa for it is interesting to note that Terrab et al. (2003a) also found high values for Moroccan eucalypt honeys: mean value was $0.72 \pm 0.15$ and range 0.34 $0.89 \mathrm{mS} / \mathrm{cm}$ while for Libyan honeys from $E$. camaldulensis a value of 0.44 is given for the 
conductivity (Owayss, 2005). But here another factor may be of influence for a more liberal criterion of minimal $60 \%$ eucalypt pollen was used to define this honey type.

\subsection{Chemical analyses and honey quality}

Although the enzyme activity and the HMF content of honey usually bear no direct relationship to the botanical origin of the product some honey types, like Citrus honey, are characterized by a naturally low enzyme content. In general these two parameters are used as quality criteria. Too strong heating and too long storage damage the enzyme activity and increase the HMF content, which is fixed at $40 \mathrm{mg} / \mathrm{kg}$ in the honey standards (Codex Alimentarius Commission, 2001; European Commission, 2002; IHC website). An exception has been made for honeys from tropical regions for which this limit is $80 \mathrm{mg} / \mathrm{kg}$. Only two samples $(4 \%)$ had a HMF content of more than $40 \mathrm{mg} / \mathrm{kg}$ : sample E12 with $110.7 \mathrm{mg} / \mathrm{kg}$ and sample E30 with $124.0 \mathrm{mg} / \mathrm{kg}$. Especially the latter sample is an example of a honey which has undergone prolonged heating for its diastase activity was below the international limit of 8 Schade units and no invertase activity at all was noticed. As four other samples had a too low diastase index the total number of honeys which did not comply with the regulations was five (8\%).

It should be remarked that in our study the HMF values were somewhat higher (mean $17.2 \mathrm{mg} / \mathrm{kg}$ ) than for European honeys which are usually below $10 \mathrm{mg} / \mathrm{kg}$. The hot Algerian climate may be the cause of this phenomenon for similar heat damage was also observed in the mean diastase number of the investigated eucalypt honeys, which was 15.9 Schade units, while for European eucalypt honeys the mean value is 25.5 Schade units. In line with our data Jilani et al. (2008) reported for Tunisian multifloral honeys HMF and diastase values which also showed heat influence (HMF 21.3, range $3.0-39.6 \mathrm{mg} / \mathrm{kg}$; diastase 17.6 , range 3.0-39.6). Concerning the invertase numbers of our Algerian honeys: it turned out that the samples with the lowest values came from the drier and hotter regions of our country.
As may be concluded from Table III the mean contents of glucose and fructose were about the same for the multifloral and eucalypt honeys. The content of the sum of these two sugars was in general above $60 \%$ in agreement with the fixed limits for nectar honey as mentioned in the international honey standards. Honeys with lower values, as found in our samples E56 (58.9\%) and especially E58 $(55.2 \%)$, are considered as wholly or partly been derived from honeydew. The amount of sucrose in all honey samples varied between 0 and $4.3 \%$; all values were within the limits of 5\% in general and 10\% for eucalypt honeys. The sugars trehalose, melicitose and raffinose, characteristic for honeydew, were only present in small amounts, indicating that honeydew was only scarcely present or not at all, except for sample E58 which was also identified by its $\mathrm{pH}$ value as partly derived from honeydew.

\subsection{Statistical analyses}

Honeys from the region south differed statistically significant in $\mathrm{pH}$ from honeys from the other regions (ANOVA: $F=12.410 P=$ $0.000)$. For the other parameters there was no difference. PH influence may mainly be due to geographical characteristics as the soil in the steppic and presaharan ecosystems in the south is definitely rocky and more alkaline (Nedjraoui, 2001). A much smaller pH influence may arise from a botanical effect for two honeys from this area are mixtures of blossom and honeydew honey.

Concerning the correlation analysis (Tab. IV) it is interesting to note that similar results were also reported from Spain. In their study on Andalusian honeys Serrano et al. (2007) found a correlation between the enzymes diastase and invertase (correlation coefficient 0.85 ). In our study this correlation is somewhat lower probably due to our hot climate coupled with the fact that the enzyme diastase is more heat resistant than invertase.

\section{CONCLUSIONS}

On basis of palynological analysis it can be concluded that the rather characteristic 
combination of pollen from Eucalyptus species, Olea europaea, Papaver rhoeas, Pimpinella anisum, Carduus sp. and Hedysarum coronarium may give a preliminary characterization of the pollen spectrum of Algerian honeys. The main honey producing plants are Eucalyptus spp., Hedysarum coronarium and clover spp. Daucus carota and Pimpinella anisum are important honey plants in the regions west and centre and Echium plantagineum in the regions centre and east. Unifloral honeys are mainly harvested from Eucalyptus and Citrus trees and especially the presence of pollen from $P$. rhoeas and Centaurea species allows the differentiation of Algerian eucalypt honeys from other eucalypt honeys produced in the western Mediterranean area.

The quality of Algerian honey, assessed by determining some important physicalchemical parameters, is, generally speaking, not disappointing as the majority of the honey samples $(88 \%)$ did comply with the international standards (Codex Alimentarius Commission, 2001; European Commission, 2002; IHC website). The honeys are characterized by low moisture content and by a relative high electrical conductivity. The main problem is too strong heating, resulting in a too low diastase number ( $8 \%$ of the samples) or too high HMF content ( $4 \%$ of the samples). In order to produce a high quality product, which will also be accepted on the international honey market, it will still be necessary to improve the beekeepers' knowledge on honey harvesting techniques, honey processing and storage.

Caractérisation des miels algériens par des méthodes palynologiques et physico-chimiques.

\section{Algérie / conductivité électrique / miel / compo- sition / melissopalynologie / sucre}

Zusammenfassung - Charakterisierung von algerischen Honigen mit palynologischen und chemisch-physikalischen Methoden. Die Imkerei spielt in den Küstenregionen Algeriens eine wichtige Rolle. Den größten Nektareintrag findet man in den Monaten April, Mai und Anfang Juni. Da es bisher nur wenig Publikationen zum Pollenspektrum und den chemisch-physikalischen Eigenschaften von algerischen Honigen gibt, wurde eine Un- tersuchung an 66 Honigproben aus 22 Sammelorten in 4 unterschiedlichen Regionen durchgeführt, einschließlich 14 Eukalyptushonigen aus der Region des Kleinen Atlas. Die Sammelplätze sind in Abbildung 1 und Tabelle I aufgeführt. Die Ziele waren, das Pollenspektrum zu charakterisieren, die chemisch-physikalischen Eigenschaften zu definieren und die Daten mit denen von Honigen aus den westlichen Mittelmeerregionen zu vergleichen. $\mathrm{Zu}$ sätzlich wurde die Übereinstimmung der Werte mit den Richtlinien der EU überprüft. Bestimmt wurden die Gesamtpollenmenge, Pollenart, Wassergehalt, $\mathrm{pH}$, Leitfähigkeit, Diastase, Invertase, HMF und elf verschiedene Zucker. Für die quantitative und qualitative Pollenanalyse wurde die Methode nach Louveaux-Maurizio-Vorwohl benutzt, für die chemisch-physikalischen Analysen wurden die harmonisierten Methoden der europäischen Honey Commission verwendet. In Tabelle I sind die Sammelplätze, die Anzahl der Pollenkörner in $10 \mathrm{~g}$ Honig, die Repräsentativität der einzelnen Pollenarten entsprechend der Klasseneinteilung nach Maurizio sowie die beiden jeweils vorherrschenden Pollenarten in den Proben aufgeführt.

Die quantitativen Analysen ergaben zwischen 2, $1 \times$ $10^{3}$ und $1,12 \times 10^{6}$ Pollenkörner pro $10 \mathrm{~g}$ Honig (PG/10). Dabei wurden insgesamt 124 Pollenarten identifiziert. In den meisten Proben wurden Pollen von Eucalyptus-Arten (77\%), Olea europaea (Olivenbaum, $71 \%$ ), Papaver rhoeas (Klatschmohn, $62 \%$ ), Pimpinella anisum (Anis, $61 \%$ ) und Carduus sp. (Distel, $59 \%$ ) gefunden, während Hedysarum coronarium in $50 \%$ der Proben nachgewiesen wurde. O. europea und $P$. rhoeas liefern zwar keinen Nektar, sind dafür aber gute Pollenquellen für Bienen. Das Vorkommen der 30 wichtigsten Pollenarten ist in Abbildung 2 dargestellt.

In den unifloralen Eukalyptushonigen waren Echium plantagineum, Olea europaea, Trifolium spp, Papaver rhoeas, Centaurea sp. und Apiaceae die wichtigsten Begleitpollen. Der Nachweis von $P$. rhoeas und Centaurea-Arten ermöglicht eine $\mathrm{Ab}$ grenzung der algerischen Eukalyptushonige von Eukalyptushonigen aus anderen Mittelmeerregionen.

Die chemisch-physikalischen Analysen (Tab. II und III) zeigen, dass algerische Honige einen geringen Wassergehalt und eine relativ hohe elektrische Leitfähigkeit haben. Die HMF-Werte waren etwas höher und die Diastaseaktivitäten etwas geringer im Vergleich zu europäischen Honigen. Außer beim pH-Wert gab es bei den chemisch-physikalischen Parametern keine Unterschiede zwischen den 4 Regionen. Die Mehrzahl der Honigproben (88\%) erfüllten die internationalen Standards des Codex Alimentarius und der Europäischen Kommission.

\footnotetext{
Algerien / elektrische Leitfähigkeit / Honig / Melissopalynologie / Zucker
} 


\section{REFERENCES}

Bogdanov S., Martin P., Lüllmann C. (1997) Harmonised methods of the European Honey Commission, Apidologie 28, extra issue, 1-59. Updated 2009 publication via International Honey Commission http://www.bee-hexagon.net/en/ network.htm Choose Publications: Harmonised methods of the European Honey Commission (accessed on 25 September 2009).

Chefrour A., Tahar A., Origine botanique des miels des régions semi arides (Algérie), http://www. beekeeping.com/articles/fr/miels_alegriens.pdf (accessed on 25 June 2009).

Chefrour A., Battesti M.-J., Ait K., Tahar A. (2007) Melissopalynologic and physicochemical analysis of some north-east Algerian honeys, Eur. J. Sci. Res. 18, 389-401 (http://www.eurojournals.com/ ejsr\%2018\%203.pdf) (accessed on 25 June 2009).

Codex Alimentarius Commission (2001) Codex standard 12, Revised Codex Standard for Honey, Standards and Standard Methods 11.

Damblon F. (1987) Miels de Thym du Maroc. II. Étude palynologique des sources mellifères, Al Birunya. Rev. Mar. Pharm. 3, 51-75.

Damblon F. (1988) Caractérisation botanique, écologique et géographique des miels du Maroc, Inst. Fr. Pondichéry, Trav. Sec. Sci. Techn. XXV, 309-329.

European Commission (2002) Council Directive 2001/110/EC of 20 December 2001 relating to honey, Off. J. Eur. Communities L10, 47-52.

Hadjiat K. (1997) État de dégradation des sols en Algérie, Rapport d'expert Office National pour l'Environnement, Banque mondiale, Washington, DC.

Hussein M.H. (2000) A review of beekeeping in Arab countries, Bee World 81, 56-71.

IHC website, International Honey Commission http:// www.bee-hexagon.net/en/network.htm. Choose Publications (accessed on 25 September 2009).

Jilani I.B.H., Schweizer P., Khouja M.L., Zouaghi M., Ghrabi Z. (2008) Physicochemical spectra of honeys produced in Tunisia (Southwest of Kef), Apiacta 43, 38-48 (accessed on 27 June 2009).

Journal Officiel Français (1977) Arrêté du 15 février 1977 relatif aux méthodes officielles d'analyse du miel, pp. 1-30.

Louveaux J., Abed L. (1984) Les miels d'Afrique du nord et leur spectre pollinique, Apidologie 15, $145-170$.

Louveaux J., Maurizio A., Vorwohl G. (1978) Methods of Melissopalynology, Bee World 59, 139-157.

Makhloufi C., Schweizer P., Azouzi C., Persano Oddo L., Choukri A., Hocine L., Ricciardelli D'Albore G. (2007) Some properties of Algerian honey, Apiacta 42, 73-80.

Nedjraoui D. (1981) Évolution des éléments biogènes et valeurs nutritives dans les principaux faciès de végétation des hautes plaines steppiques de la wilaya de Saida, Thèse $3^{\mathrm{e}}$ cycle, Université des Sciences et de la Technologie Houari Boumediene, Alger.

Nedjraoui D. (2001) Country Pasture/Forage Resource Profiles: Algeria, http://www.fao.org/ag/AGP/ AGPC/doc/counprof/Algeria/Algeria.htm (accessed on 12 October 2009).

Ouchemoukh S., Louaileche H., Schweizer P. (2007) Physicochemical characteristics and pollen spectrum of some Algerian honeys, Food Control 18, $52-58$.

Owayss A.A. (2005) Physicochemical analysis for standardizing quality criteria of Libyan Eucalyptus (Eucalyptus sp.) honey, Egypt J. Appl. Sci. 20, 247-255 (http://www.fayoum.edu.eg/ Agriculture/PlantProtection/pdf/DrAyman7.pdf) (accessed on 27 June 2009).

Persano Oddo L., Piro R. (2004) Main European unifloral honeys: descriptive sheets, Apidologie 35 (Suppl. 1), S38-S81.

Ricciardelli D'Albore G., Vorwohl, G. (1980) Sortenhonige im Mittelmeergebiet, Rivista Agricoltura Subtropicale e Tropicale 74, 89-118.

Ricciardelli D'Albore G. (1998) Mediterranean melissopalynology, Instituto di Entomologia Agraria, Università degli studi, Perugia, Italy.

Schweizer P. (1998) Sur les sentiers des miels de France, Histoire d'eau, $2^{\mathrm{e}}$ partie, L'Abeille de France, 844.

Seijo M.C., Aira M.J., Mendez J. (2003) Palynological difference in pollen content of Eucalyptus honey from Australia, Portugal and Spain, Grana 42, 183-190.

Serrano S., Espejo R., Villarejo M., Jodral M.L. (2007) Diastase and invertase activities in Andalusian honeys. Int. J. Food Sci. Technol. 42, 76-79.

Terrab A., Díez M.J., Heredia F.J. (2003a) Palynological, physico-chemical and colour characterization of Moroccan honeys: I. River red gum (Eucalyptus camalduensis Dehnh) honey, Int. J. Food Sci. Technol. 38, 379-386.

Terrab A., Díez M.J., Heredia F.J. (2003b) Palynological, physico-chemical and colour characterization of Moroccan honeys: II. Orange (Citrus sp.) honey, Int. J. Food Sci. Technol. 38, 387-394.

Terrab A., Díez M.J., Heredia F.J. (2003c) Palynological, physico-chemical and colour characterization of Moroccan honeys: III. Other unifloral honey types, Int. J. Food Sci. Technol. $38,395-402$.

Terrab A., Valdés B., Díez J. (2003d) Pollen analysis of honeys from the Mamora forest region (NW Morocco), Grana 42, 47-54.

Von der Ohe W. (1994) Unifloral honeys: Chemical conversion and pollen reduction, Grana 33, 292 294.

Von der Ohe W., Persano Oddo L., Piana M.L., Morlot M., Martin, P. (2004) Harmonized methods of melissopalynology, Apidologie 35 (Suppl. 1), S18-S25.

Vorwohl G. (1973) Das Pollenbild der tunesische Honige, Apidologie 4, 178-179. 